\title{
"The fishery went away": The impacts of long-term fishery closures on young people's experience and perception of fisheries employment in Newfoundland coastal communities
}

\author{
Nicole G. Power ${ }^{1}$, Moss E. Norman ${ }^{2}$ and Kathryne Dupré ${ }^{3}$
}

\begin{abstract}
There is a growing body of research documenting the impacts of fisheries collapses on communities and fisheries workers. Less attention has been paid to the sustainable use of fisheries resources so that future generations have access to these resources, or to the creation of mechanisms that might contribute to the intergenerational continuity of recruitment of fisheries workers and the regeneration of fisheries communities. In this paper we report on young people's experiences and perceptions of fisheries employment in Newfoundland and Labrador to deepen our understanding of the resiliency of small-scale fisheries. We found that these young people's experiences of fisheries employment are extremely limited and their perceptions of the quality of fisheries work is primarily negative while, at the same time, they recognize its importance to the vitality of their communities. We argue that stock collapses and subsequent downsizing and regulatory changes in the industry have disrupted intergenerational continuity in fisheries work and shaped how young people view their communities and options.
\end{abstract}

Key Words: fisheries; community; employment; resiliency; youth

\section{INTRODUCTION}

The devastating impacts of fisheries collapses on communities and those who depend on the resource for a living have been well documented (see Neis et al. 2005, Ommer and Team 2007), but we know less about their impacts on the intergenerational resiliency of fisheries. From an intergenerational equity perspective, the resiliency of small-scale fisheries depends on the sustainable use of fisheries resources for future generations, as well as mechanisms that attract and support the recruitment of new generations of fisheries workers (Neis et al. 2013). In the case of Newfoundland and Labrador, young people have fewer employment options in fisheries than previous generations. In the last 20 years, the fishing industry has experienced declines in employment in the harvesting and processing sectors, a reduction of $35.2 \%$ and $50.8 \%$ between 1989 and 2010, respectively (MOU Steering Committee 2011). These declines are due to plant closures, the reduced number of fishing enterprises, professionalization mechanisms that restrict fish harvester membership, and the increased costs of enterprises (Power 2005, 2008, Neis et al. 2013). It has also become difficult to recruit younger workers to the industry (MacDonald et al. 2013). The result has been an aging fisheries workforce. According to the Professional Fish Harvesters Certification Board (in MOU Steering Committee 2011), in 1999 approximately 20\% of registered fish harvesters were under the age of 30 compared with approximately $9 \%$ in 2009 . During the same period there was a rise in the proportion of harvesters over the age of 55 , from $10 \%$ to $29 \%$ (MOU Steering Committee 2011). Over a shorter period of time, the processing sector has experienced a significant rise in the proportion of workers over the age of 55, from $12 \%$ in 2004 to $24 \%$ in 2009 (Department of Fisheries and Aquaculture, as cited in MOU Steering Committee 2011).

Given this aging workforce, and its potential implications for resiliency, it is important to examine young people's experiences and understandings of fisheries and consider what this can tell us about barriers to recruitment of youth into small-scale fisheries in Newfoundland and Labrador. Palmer and Sinclair's work (2000) on high school students on the Northern Peninsula found that many youth were not interested in pursuing fisheries-related employment in their communities and instead expected to move to a more urban location for employment. In their case study of a Newfoundland fisheries community postmoratorium, Jackson et al. (2007) found that although young people saw their communities as safe and healthy places where they could enjoy freedom and the outdoors, they were also experiencing losses of recreational and work opportunities, friends and family through outmigration, and community vitality, with negative consequences for their health. In this article we build on this research by drawing on the findings of the Rural Youth and Recovery component of the Community-University for Recovery Research Alliance (CURRA). The fishery can serve as a symbolic and material site of belonging for youth in Newfoundland and Labrador (see Power et al. 2014), but here, building on Neis et al. (2013), we focus on their experiences and perceptions of employment options in Newfoundland and Labrador, and consider what this means for the resiliency of small-scale fisheries.

\section{CONCEPTUAL FRAMEWORK}

The ecological side of the fisheries crisis in Newfoundland and Labrador is well recognized now (see Hutchings and Myers 1995) but we know less about the generational social impacts of longterm fisheries closures. Most young people have grown up in a context of fisheries and processing plant closures, rural depopulation, and outmigration. Therefore, what impact has this had on Newfoundland youth and what are the implications for the resiliency of small-scale fisheries? Sumaila (2004) has argued for the integration of an intergenerational perspective in traditional cost-benefit analyses of fisheries to identify the benefits and allocate the costs of efforts to rebuild stocks across generations. Likewise, Khan and Neis (2010) make the point that efforts to rebuild fish stocks must be paired with attention to the 
next generations and communities as beneficiaries. Here, we focus on the dynamics (experiences and perceptions of youth) that might contribute to the resiliency of the next generation of fisheries workers. From a social generational perspective (Wyn and Woodman 2007, Furlong et al. 2011), young people's experiences and perceptions of fisheries work in relation to the broader social, political, and economic context are very revealing, and play a crucial part in the resiliency of small-scale fisheries and communities. Drawing on the social-ecological, and psychology and mental health literatures, Berkes and Ross (2013:13) develop an understanding of community resilience "as a function of the strengths or characteristics that have been identified as important, leading to agency and self-organization." Such strengths or characteristics include "people-place connections; values and beliefs; knowledge, skills and learning; social networks; engaged governance (involving collaborative institutions); a diverse and innovative economy; community infrastructure; leadership; and a positive outlook, including readiness to accept change." Framed this way, we examine the ways in which young people's experiences and perceptions about fisheries employment and communities contribute (or not) to regeneration. At the same time, a social generation perspective situates their experiences and perspectives in the wider politicaleconomy.

\section{CONTEXT}

The qualitative research for the Rural Youth Recovery component of the CURRA was conducted on the west coast of the island of Newfoundland. Focus groups were conducted in the communities of Port aux Basques, Codroy, Isle aux Morts, and Burnt Islands on the southwestern tip of the island, in Burgeo, to the east of this point, and in Stephenville, Trout River, and Woody Point further north up the western coast of Newfoundland. Based on the 2006 census, Port aux Basques (population of 4880) and Stephenville (population of 6875), which is about 170 kilometers north of Port aux Basques, were the largest communities and serve as regional service hubs for smaller surrounding communities (Community Accounts 2006). Codroy had the smallest population (295), while Burnt Islands and Isle aux Morts had 710 and 725 residents, respectively. Further up the coast from Stephenville, Trout River had 630 residents and Woody Point had 355 residents. East of Port aux Basques, Burgeo had 1630 residents and was the most remote community in the study, some 180 kilometers away from the next largest center (Stephenville; Community Accounts 2006).

All communities in the study had experienced population decline between the 2001 and 2006 censuses, with the exception of Trout River, which experienced a slight population increase $(1.6 \%)$. Notwithstanding the population increase in Trout River, population decline was more pronounced in the smaller communities (Community Accounts 2006). For example, Port aux Basques experienced a 2.2\% and Stephenville a $6.6 \%$ decline in population as compared to Codroy, which experienced almost a $18 \%$ decline, with the other communities experiencing somewhere between a 3\% (Woody Point) and 11.8\% (Burnt Islands) decline over the same time period. The comparative population stability of Port aux Basques may be partially accounted for by the inmigration of residents from more remote locations in search of work opportunities and access to retail and service resources. If we go back to the early 1990 s, to the period when the federal government imposed closures on certain groundfish stocks, the declines are more dramatic. For example, according to the 1991 census, Port aux Basques had a population of 6100, Burgeo 2400, Isle aux Morts 1145. The stark population decline these places experienced from the early 1990s onward is shared by the other communities involved in the research. Moreover, this pattern of decline is not merely a west coast of the island phenomenon, but is reflective of the general trend in the province of Newfoundland and Labrador, which has experienced an overall population decline in the last 20 years, from 580,109 people at its peak in 1992 , to 512,900 in 2011. Young people make up the largest proportion of those migrating out of the province, a trend that, when combined with declining birth rates, has resulted in a net loss of youth (Canadian Policy Research Networks 2009).

The importance of fish-related industries to the local economy differed across the communities where the research was conducted. Given that there is considerable mobility among the workforce (residents from one community will commute to another for work), we have elected to examine statistical data for local regions as opposed to specific communities. Using the most recently available data from the 2006 census, we found that fishing continues to be a significant part of the economy in the regions we researched, comprising between $6 \%$ (Stephenville region) to $23 \%$ (Bonne Bay region) of available occupations, as defined by Statistics Canada. More specifically, fishing related industries constituted approximately 10\% (325/3225 occupations) of the occupations in the Port aux Basques region, including Isle aux Morts and Burnt Islands, and 16\% (255/1545) in the Burgeo region. Perhaps unsurprisingly, fishing was generally more important to small, single-industry communities, such as those in the Bonne Bay region, which includes Trout River and Woody Point, whereas in the regions that contained larger, more diverse, service-oriented economies, such as those that included Port aux Basques and Stephenville, fishing tended to be less prominent. Furthermore, significant industry changes have occurred in some regions since 2006, so the figures are dated: the Burgeo fish plant has gone, and the region continues to go through cycles of relative prosperity and scarcity (see Philpott 2012), and so the census data, although the best available, are somewhat distorted.

\section{METHODS}

\section{Qualitative methods}

The Rural Youth and Recovery component of the CURRA employed a mixed methods research design that included focus groups, interviews, photovoice, and an online survey. Data for the qualitative portion of the Rural Youth and Recovery component were collected between April 2009 and June 2010. Our overall purpose for the focus groups, interviews, and photovoice methods was to gain insight into how youth living in coastal communities understood and experienced work in their communities: we asked questions about what life was like for young people growing up in their communities, the availability and quality of jobs in their community, and how the job market had changed over the years. We were particularly interested in the issue of youth outmigration and the factors that influence young people's decision to stay, leave, or return to their communities. In follow up questions, we asked about fishing-related industries as well as probing for further information when participants brought up fisheries during focus group discussions, but we did not ask directly about 
fishing, because we were interested in young people's perspectives on the full range of work opportunities and what was relevant to them. Focus groups were conducted in quiet locations in local, accessible facilities, such as schools, hospitals, community centers, and the Community Youth Network facilities. The sessions lasted between 35 minutes and 1 hour for the younger age groups (12-15 years) and 1 hour to 2.5 hours for older participants (16-24 years) depending on how much time was available and how much the participants had to share. Participants also completed a short demographic questionnaire that included queries about family members' employment histories.

Beyond this, we carried out one-on-one interviews with young people and adults that focused on recreation opportunities and the experiences of youth in rural Newfoundland. The interviews were semistructured and included general questions such as "What do people your age do for fun around here?" and "Has this changed since you were younger?" as well as more specific prompts, such as "Tell me the sorts of things you do for fun on a typical day after school." The interviews lasted between 35 minutes and 1.5 hours, and were conducted in semiprivate locations that were convenient for participants. For the final component of the qualitative part of our work, we employed the photovoice method with 11 youths. Participants were given digital cameras and instructed to take pictures of the places, things, and people in their communities that mattered to them. After a predetermined period of time (between three days and a week), the researcher met with the participants in a semiprivate location and engaged in a photo-elicitation discussion, where small groups of participants shared and discussed the photos they had taken. These photo-elicitation discussions lasted between 35 minutes and 1.5 hours.

All focus groups, interviews, and photo-elicitation sessions were audio recorded, except for one interview in which the participant did not want to be recorded and where the researcher took extensive notes. All audio recordings were transcribed verbatim, and participants have been given pseudonyms to mask their identity. Transcripts for all 18 focus groups were uploaded to the data management software system NVivo 10, and were independently coded by Power and Norman using a thematic analysis. We met several times during this process to discuss and refine emergent themes. Transcripts (without NVivo) from oneon-one interviews and photo-elicitation discussions were thematically organized and analyzed.

\section{Recruitment and characteristics of participants}

For the qualitative portion of the study, youth were defined as being between the ages of 12 and 24 years and were recruited primarily through our community partner, the Community Youth Network, and secondarily through the Western School District. We conducted 18 focus groups with young people $(\mathrm{N}=91,38$ male, 53 female). Participants were divided into three age groups (12-15 years, 16-18 years, 19-24 years), with six focus groups in each age category. Most of the focus groups (12 of 18) were conducted in the communities in the southwest part of the island, with additional focus groups in Burgeo $(\mathrm{N}=2)$, Woody Point $(\mathrm{N}$ $=2)$, Trout River $(\mathrm{N}=1)$, and Stephenville $(\mathrm{N}=1)$. Our strongest community connections were with the Community Youth Network in Port aux Basques, which services surrounding communities, and as the project progressed we developed connections with the school in Port aux Basques as well. About halfway through data collection, research relations were further developed with the Community Youth Network operating in other communities (Stephenville and Burgeo) as well as in other schools in the Western School District (Trout River and Woody Point). Participants for the one-on-one interviews ( $\mathrm{N}=13$ youth, 8 male, 5 female) were purposively sampled from the focus group participants $(\mathrm{N}=4)$ as well as through consultations with staff from Western School District $(\mathrm{N}=5)$. Adult interviews $(\mathrm{N}=6$, all female) were conducted with local recreation providers, e.g., director of the community recreation services or school coaches, and snowball sampling was utilized to recruit participants. All one-on-one interviews were conducted with participants from the southwestern communities. Finally, the photovoice component of the study was conducted with 11 youth (12-24 years). Photovoice participants were purposively selected, based on age and gender, from the focus group participants. However, only 7 ( 6 female, 1 male) of the 11 participants were able to participate in the photo-elicitation portion of the project because of scheduling difficulties.

Among our participants, there was a small, but consistent trend of migration from smaller communities to larger hubs. For example, with the 19-24 year-old focus group participants, demographic surveys revealed that although 20 ( 8 male, 12 female) participants grew up in smaller communities, and 8 grew up in larger regional hubs, half of the participants $(\mathrm{N}=14,6$ male, 8 female) identified a regional hub, e.g., Port aux Basques, as their current community of residence. In other words, roughly $21 \%$ of those youth who grew up in smaller communities had moved to larger, regional centers. The migration trend was almost exclusively in one direction; only one participant identified growing up in a center and moving to a smaller community, and even then she listed her place of residence as split between a smaller community and the larger center of Port aux Basques. With respect to 16-18 year-old participants, the overwhelming majority of our participants lived in smaller communities $(69 \%)$. This is partly related to the communities from which participants were recruited, including smaller, more isolated communities, such as Burgeo, Woody Point, and Trout River and was not the case for 19-24 year-old participants who were mostly recruited from Port aux Basques and the surrounding area. It was also related to the fact that most of our 16-18 year-old participants were still living at home with their parents.

\section{Online survey}

Youth between the ages of 16 and 29 took part in an online, province-wide survey designed to expand upon the issues identified through our qualitative work and the existing literature on the employment experiences of young people (e.g., Barling et al. 2002). The target sample for this survey was youth living both in and outside the province, to ascertain the views of both sets of youth. Questions were designed to assess young people's substance abuse, stress, social support, psychological health, work engagement, job burnout, workplace safety, workplace incivility, life satisfaction, and recovery from work, using established valid and reliable scales to measure these. Where such survey measures do not presently exist for the variables with which we were concerned, we created them using recommended methodologies for creating valid, reliable measures (e.g., Fowler 1995, Tourangeau et al. 2000). Specifically, we created measures for 
assessing young people's perceptions of various community issues, as well as their experiences in the fishing industry, their perceptions of the fishing industry, and how important fishing is to them, their families, and their communities.

\section{Recruitment and characteristics of participants}

To recruit youth for participation in this survey, we first sent an e-mail request to youth via regional youth organizations, asking them to participate in the online survey. The survey link was posted on the provincial government's Youth Retention and Attraction Strategy website. We also posted advertisements at approved locations and emailed students in one regional postsecondary institution. In all cases, potential participants were given some information about the study and were told that participants must have work experience and be between the ages of 16 and 29. Each respondent had the chance to win one of five $\$ 100$ gift cards in exchange for his/her participation. Our recruitment of youth participants resulted in 152 usable surveys (166 were returned but 14 contained mostly missing data so were not included in subsequent analyses). Given our recruitment strategy, it is impossible to know how many young people the survey request reached, and as such a response rate calculation is not provided.

Young people who participated in the survey were of average age 22 years ( 35 male, 117 female), and 147 of them reported currently living in the province. Of those, $37.5 \%$ reported that they had graduated from college or university, and $30.6 \%$ reported that they were currently in school. Although we wished to both extend and also support our qualitative findings, it is possible that, given the proportionately greater number of young women to young men in the sample, our results may not be representative of young people in general. Demographic data provided by the 152 participants told us that $44.1 \%$ of them have lived in a city/town with a fishing industry and $27.6 \%$ have not, while the remaining $28.3 \%$ did not provide us with that information.

\section{RESULTS}

Young people's opportunities to access fisheries jobs and their related work experiences

In the youth focus groups, young people were asked questions to stimulate discussion on particular themes: types of jobs available, relationships with coworkers, training, health and safety, work and life balance, as well as what they envisioned working at in the future, what might make their communities ideal places for work and life, and what they do outside of work. Across the focus group discussions, youth clearly stated that they saw few if any opportunities to participate in fisheries work. For some, reduced opportunities in harvesting were linked to declines in the fish stocks:

Interviewer: Are people still fishing here?

Jessica: Yes.

Sarah: Just a couple boats, right?

Jessica: Some people goes over to Nova Scotia and fishes off there.

Interviewer: Why is that, do you know?

Sarah: Just not enough fish, I guess.

Interviewer: Okay, just not where the fish are, okay.

Sarah: Yeah, they're not around here anymore (Focus

Group, 19-24 years old).
Others suggested that the little harvesting work that remained was largely the preserve of older people: "It's basically, like, older people, like in their fifties and sixties [that are fishing] ... not like, the young ones in their twenties. They goes out to Alberta somewhere" (Male, Focus Group, 12-15 years old).

Youth also described a lack of jobs in fish processing for youth, specifically the disappearance of summer employment for students:
Interviewer: Do a lot of people work at the fish plant? Amy: Not really, not like it used to be. It used to be a big thing.
Olivia: Yeah, summer jobs used to be really, students used to be like twenty students or something every year. And then there's barely anything there now for students.
...
Amy: Yeah. My mom used to work down there. Like even older people used to work down there, but now it's mainly just for a couple of students...
$\cdots$ Interviewer: And now there's just a few people working there now? [Yeah] So what changed, what happened? Olivia: The fishery went away. I think the fishery has gone way down (Focus Group, 12-15 years old).

This exchange points to an increase in the precarious nature of fish processing work, making the job less suitable for or attractive to older workers and indeed less of an option for younger workers. This is echoed in the following excerpt:
Jessica: ... young people now, some of them go work at the fish plant, but you wouldn't see an older person going to work there now.
Sarah: Nope.
Interviewer: Why is that? Any idea why that is?
Jessica: Well, there's just not enough work over there now and the older ones don't want to bother with it. A lot of the older ones used to work there when it was at its biggest. Interviewer: Were the wages different when it was at its biggest do you think? Or was it just more work to be done? Sarah: Just more work to be done.
Interviewer: So it was full time work?
Sarah: Yeah (Focus Groups, 19-24 years old).

Similarly, survey findings suggest that, regardless of young people's experience with fishing, in terms of previously living in a city/town with, or working in, the fishing industry, they generally indicated that there is a lack of job opportunities in the fishing industry. Only $18 \%$ of all participants agreed or strongly agreed that there are job opportunities in the fishing industry. Table 1 shows the results of comparing young people's responses based on their experience with the fishery, i.e., whether they had lived in a city/town with a fishing industry and/or worked in a fishing industry; because of missing data only 107 participants were included in this comparison. Overall, young people tended to disagree that there are job opportunities in the fishery.

Not surprisingly given prolonged moratoria and reduced processing work opportunities for young people linked to plant closures, downsizing, and the effect of seniority systems, only a small minority of young people in the qualitative study $(\mathrm{N}=5)$ described having experience in fishing or working in fish plants, 
Table 1. Job opportunity survey responses. Total number of participants in this analysis $=107$.

\begin{tabular}{|c|c|c|c|}
\hline \multirow[b]{2}{*}{ Fishery Experience } & \multicolumn{3}{|c|}{ Are there job opportunities in the fishery for you? } \\
\hline & Strongly Disagree or Disagree & Neither Agree nor Disagree & Agree or Strongly Agree \\
\hline $\begin{array}{l}\text { Lived in a city/town with a fishing } \\
\text { industry and worked in a fishing } \\
\text { industry }(n=7)\end{array}$ & $42.9 \%(3$ people $)$ & $42.9 \%(3)$ & $14.3 \%(1)$ \\
\hline $\begin{array}{l}\text { Lived in a city/town with a fishing } \\
\text { industry }(n=59)\end{array}$ & $57.6 \%(34)$ & $23.7 \%(14)$ & $18.7 \%(11)$ \\
\hline Neither $(n=41)$ & $56.1 \%(23)$ & $34.1 \%(14)$ & $9.7 \%(4)$ \\
\hline
\end{tabular}

though some talked about knowing young people who had worked in fisheries. Four males reported formal or informal experience and most were living in more remote and rural areas. Some reported working in the industry at a very young age, e.g., 8 years old. A similar lack of involvement in fisheries work was reflected in the survey responses with only 5.3\% reporting that they have "worked in the fishing industry" (65.8\% reported that they have not "worked in the fishing industry", the rest did not respond).

Young men living in smaller and more remote communities were more likely to refer to the fishery as a potential employment option. The degree to which the youth understood fishing to be an employment option seemed to vary depending on whether the local economy either had or was close to a fish plant or had a cohort of fish harvesters. In the following exchange, a young woman from Burgeo recognized the continued importance of fisheries to the economic vitality of her community:

Interviewer: What kind of jobs do you think they could
add to this area?
[pause]
Loretta: The fish plant [laughs], if it would come back.
I guess with that, though, like with more people coming
back, like with the fish plant open, more like community
centers and stuff like that, and stores and stuff would
open, through that more stuff would open and more
people would come back and there would be more things
to do (Focus Groups, 19-24 years old).

At the same time, youth in our study were rarely encouraged by their parents or others to enter fisheries work. The results of the demographic questionnaire completed by the focus group participants indicate that of the 22 youth with one or both parents engaged in fish harvesting or processing, only two young men reported being encouraged by their fathers to engage in fisheriesrelated work. Instead, focus group participants described being encouraged to leave and/or wanting to leave their communities to pursue educational and employment opportunities in more urban or distant places. A common experience reported by the participants in the oldest age range was of moving back and forth between communities on the (south)western coast of Newfoundland as well as to more distant locations off the island, in search of work, education, and life experiences. Although the mobility experiences were less pronounced for the 16-18 year-old youth (compared to the 19-24 year-olds), they strongly anticipated, some reluctantly, leaving their communities in the future for larger centers that offered, in their view, greater work and recreation opportunities.
At the same time, the focus group findings suggest that family connections continue to be an important way to enter fisheriesrelated work. Two young men reported fishing inshore in small boats with their uncles for lobster and cod and, although paid to do this work, described it as "helping out" and as being sporadic. One young man occasionally travelled with his father to work at a fish plant in the United States. Other participants reported working for pay at a local fish plant. For example one young woman sorted capelin at the plant owned by her family. Another participant reported informal participation in the fisheries and recollected his childhood experiences of working at the plant with his older brother, cutting out and selling cod tongues:

... me and my brother we used... to go up to the fish plant
and they've got this chute that comes out and when the
women are finished taking everything off the fish they
want, it comes out and it goes up a chute and into a fish
tub to be thrown into the garbage. And we were sitting
there and you would cut as much of it off the fish as you
could and take it and sell it. Like you would cut napes off
and fish tongues and heads and whatever you could, like
salvaging garbage pretty well. Might as well been out in
the dump digging through garbage and selling it (Male,
Focus Group, 16-18 years old).

Although youth in our study had few direct experiences of, and few opportunities to pursue fisheries work, our data suggest that their views on the importance of the fishery are multilayered. In terms of the importance of fishing, $14.5 \%$ of the youth surveyed (of the 107 participants who responded to this question) agreed or strongly agreed that fishing is important to their lives, while $22.4 \%$ of young people agreed or strongly agreed that fishing is important to their families and $32.9 \%$ agreed or strongly agreed that fishing is important to their communities. These distinctions in the importance of fishing for youth suggest that direct involvement in fishing work is just one of a myriad of ways that young people relate to and consider the importance of fishing and fisheries.

\section{Young people's perceptions of the quality of fisheries work}

Overall, survey participants largely disagreed or strongly disagreed $(35 \%)$ that they have had negative experiences in the fishing industry, but predominantly agreed or strongly agreed $(33 \%)$ that working in the fishing industry is a tough way to earn a living. Table 2 shows the comparisons; because of missing data 107 participants were included in this comparison. Overall, young people tended to agree that the fishery is a tough way to earn a living. 
Table 2. "Fishing is a tough way to make a living" responses. Total number of participants in this analysis $=107$.

\begin{tabular}{|c|c|c|c|}
\hline \multirow[b]{2}{*}{ Fishery Experience } & \multicolumn{3}{|c|}{ The fishery is a tough way to earn a living } \\
\hline & Strongly Disagree or Disagree & Neither Agree nor Disagree & Agree or Strongly Agree \\
\hline $\begin{array}{l}\text { Lived in a city/town with a fishing } \\
\text { industry and worked in a fishing } \\
\text { industry }(n=7)\end{array}$ & $28.6 \%(2$ people $)$ & 0 & $71.5 \%(5)$ \\
\hline $\begin{array}{l}\text { Lived in a city/town with a fishing } \\
\text { industry }(\mathrm{n}=59)\end{array}$ & $15.3 \%(9)$ & $39 \%(23)$ & $44.1 \%(26)$ \\
\hline Neither $(n=41)$ & $19.6 \%(8)$ & $36.6 \%(15)$ & $43.9 \%(18)$ \\
\hline
\end{tabular}

Likewise, the dominant perception in the focus groups was that fisheries work was a tough way to make a living: "But fishermen around here is not doing nothing. Just what they're doing is getting their stamps for the winter, right? It's a hard living" (Male, Focus Group, ages 12-15).

Not only was fishing perceived as a tough way to make a living, but fisheries jobs, particularly in fish processing, were described pejoratively. Focus group participants who had some experience working in a fish plant described it as dirty work. The young woman identified in the previous section who worked in her family's plant described it as "fun but ... stinky" and even "disgusting" (Focus Group, ages 12-15). A male youth who cut tongues with his brother described it as "the worst job you can ever have in your life" (Focus Group, 16-18 years old). In the exchange below, participants suggested some of the reasons, e.g., low wages and a lack of full-time hours, why work in the fish plant was identified as a bad job:

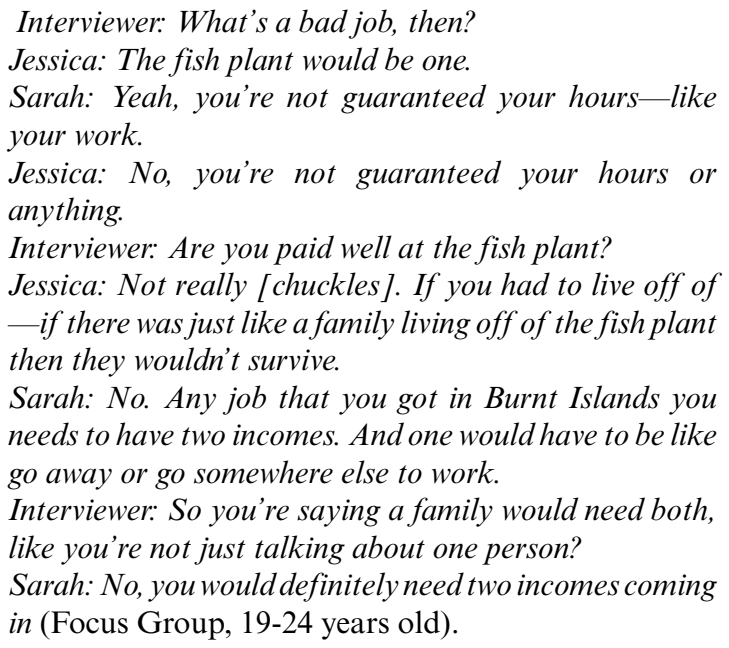

Our focus group participants experienced extremely limited opportunities to engage in fisheries work, and at the same time were dissuaded from taking up fisheries employment because of the perceived and experienced poor quality of fisheries work. This set up a tension. For example, on the one hand, word of a fish plant reopening in Isle aux Mortes was recognized as positive for the community's economy and, on the other hand, wage rates were a determining factor in decisions around entering fisheries employment:
Craig: It was only going to be a processing plant, wasn't it?

Fred: It was going be a secondary processing plant.

Interviewer: Will there be jobs there?

Fred: Yeah, they're going to - if it gets running up. It was supposed to open up in May, like the last part of this month and I don't know, it was saying something to one of the employees, 20 to 30 employees or something, so, that would be good for the community there, but...

Interviewer: Would you guys work in that? Would you guys think about working in that?

Fred: Yeah, probably.

Mitchell: Depends on rate of pay, what they pay out... (Focus Group, 19-24 years old).

In the photo-elicitation and focus group discussions, some youth raised the point that tourism is increasingly important for their communities given the decline of fish harvesting and processing work. Tourism-related jobs tend to focus on the rural and remote character of the communities, as well as on the historical dependence of fisheries, characteristics that participants valued and identified as valuable.

Mark: It [tourism] gives a good name for our town too. Interviewer: Does it?

Mark: Yeah.

Haley: Yeah. Like down in Rose Blanche where we have the Friendly Fishermen (restaurant) and we have the lighthouse.

Pamela: Yeah, a lot of people go down to Rose Blanche to see the lighthouse.

Haley: I've seen cars from places like Florida and everything like that, it's pretty cool.

Interviewer: And do you like that?

Haley: Yeah, it's nice seeing other people come around and seein' where I live and they all think it's amazing and I'm like, "I live here every day".

$\ldots$

Interviewer: But does it make you proud of your community to see other people?

Pamela: Oh definitely.

Haley: Absolutely. 'Cause it is like, it's a pretty place that we live, there's just not a lot to do.

Mark: We don't really notice it.

Pamela: We don't notice it because we live here!

Mark: But when they come they see all this water and 
open spaces, they think it's amazing.

Haley: Fishing boats and stages and stuff (Focus Group, ages 12-15).

However, tourism-related jobs like those at the lighthouse in Rose Blanche and the Friendly Fisherman restaurant tend to be seasonal and low waged. Focus group participants described underemployment and the paucity of opportunities for careers or employment in "good jobs" such as those in health care services, public school teaching, jobs with the ferry service in their communities as an impetus for outmigration. At the same time, the outmigration of their peers for employment and education, as well as of adults who left looking for permanent and seasonal employment, both shaped their perceptions of their community as a good place to live. Survey findings suggest that the friendship base underpinning their connection to place seems to be compromised by the outmigration of youth and adults. Among all surveyed, youth who had lived in a city/town with a fishing industry $(\mathrm{M}=3.94, \mathrm{SD}=0.98)$ reported that more of their friends had left than did youth who had not lived in a city/town with a fishing industry $(\mathrm{M}=3.33, \mathrm{SD}=1.07$; $\mathrm{t}(107) 3.03, \mathrm{p}<.05)$. Overall more youth appear to be leaving their home communities than staying, and of those who leave, few have intentions to return. Among youth, 52.9\% report moving away from the community in which they grew up, while $18.3 \%$ of youth report not moving away. For young people living away from the community in which they grew up, $10.5 \%$ reported wanting to return to live in that community, while $23.5 \%$ reported not wanting to return to live in that community (remaining responses were not applicable or missing).

\section{DISCUSSION}

In the last 20 years, the Newfoundland fisheries have shifted from cod and other groundfish to crab and other shellfish. Again, the reduction in the number of processing plants has reduced formal and informal fisheries employment options, particularly for women and youth (Neis et al. 2013). Taken together, these changes have combined to disrupt traditional patterns of recruitment into fish harvesting and processing. No longer do the remaining harvesters necessarily fish from the port in their home area. They tend to fish farther from shore, for longer periods, or to participate in very short-term fisheries, e.g., lobster, and then often look for work elsewhere. Additionally, professionalization efforts that restrict new entrants, along with the increased costs of enterprises, have severely limited opportunities for young people to enter harvesting (Power 2005, 2008).

This is a very different context from that of previous generations and poses a different challenge for young people who might wish to enter the industry and live in fisheries communities. In the years before the fisheries closures, young people in Newfoundland were recruited to inshore fish harvesting and processing work largely through family ties and along gender lines (see Nemec 1972, Faris 1979, Rowe 1991, Porter 1993, Power 2005). Young boys learned about fishing by hanging around the wharf and other spaces where men worked and talked. Later, boys were recruited as crew with fathers and uncles and entered into an informal apprenticeship relationship where they learned by doing. These kinds of intergenerational relations were enabled by fisheries that were largely small scale, inshore, and deeply tied to place; harvesters fished from small boats relatively close to shore and returned home daily. Community fish plants offered jobs to men and women, and young people often worked during the summer season or left school to take up relatively secure, and in the case of unionized plants, well-paying, yet often seasonal jobs at the local plant. Fisheries closures, subsequent downsizing, and restructuring of the industry, have disrupted boys' and young men's (mostly) access to fishing licenses and property, as well as the intergenerational ecological knowledge that come together to anchor people to place. These changes in fish harvesting and the closure of fish plants across the island mean fewer summer and longer term employment opportunities for young people that, in the past, served as a way of getting training and experience essential to entering fisheries in communities where there are few or no other options.

Twenty years after the 1993 moratorium on fishing cod in western Newfoundland, intergenerational continuity in fisheries work appears to be disrupted and young people rarely think about fisheries work as a viable option and a good job. Our findings are consistent with statistical data on age trends in the fisheries labor force in that they show few young people have entered fisheries, they have very limited experience working in the industry, and few opportunities to do so even if they wanted to (MOU Steering Committee 2011, Neis et al. 2013). They suggest this trend is likely to continue in the future even though there are reported to be labor shortages in fish processing and retirements could open up opportunities to enter fisheries, if young people have the resources to buy enterprises and the appropriate training. This finding is not surprising given long-term fisheries closures, government and industry efforts to downsize and restructure the fishing industry in the wake of collapses and evidence parents affected by the stock collapse and moratorium discouraged their children from entering fisheries. It does, however, suggest that the future resiliency of small scale fisheries may in part depend on a strategy that targets youth engagement and that also creates social and economic supports for youth to enter the industry (Neis et al. 2013, Sønvisen et al. 2011).

Although fisheries employment opportunities have declined, government and other responses to the fisheries closures have resulted in the expansion of tourism experience, employment, and marketing within Newfoundland and Labrador. Tourism might help sustain fisheries communities, but our findings suggest that the kinds of jobs normally associated with it, e.g., service sector jobs, are not the kinds that young people, particularly young men, are interested in doing, and are often more seasonal and poorly paid than fisheries were in the past. Moreover, tourism marketing and services in rural areas rely to some degree on the presence of small scale fisheries and access to locally produced seafood; the future of both is being jeopardized by lack of recruitment of young people into fisheries. There has been no attempt on the part of policy makers to link fisheries and tourism development explicitly to promote synergies between them and thus the future resilience of coastal communities (Lowitt 2011, Murphy and Neis [date unknown]). The "either fisheries or tourism" approach is unlikely to produce sustainable industry or communities. The combination, with a strong focus on synergies, might be quite attractive to some young people.

The federal and provincial governments have not developed a strategy for supporting young people's entry into fisheries (Neis 
et al. 2013). Instead, the provincial government has focused on curbing youth outmigration by encouraging training in the skilled trades to supply labor for mega-industrial projects (see for example Advanced Education and Skills 2012), and more recently fostering youth engagement in entrepreneurship. Together with the broader discourse of the presumed inevitability of fisheries decline, it appears that the perception of fisheries work and communities may be changing across generations.

Elsewhere Power $(2005,2008)$ has argued that the recent regulatory changes in fish harvesting, e.g., individual quotas and professionalization, have changed the nature of fishing work and produced new subjectivities among those harvesters who have been able to remain in the industry. In particular, younger fish harvesters tend to position themselves as entrepreneurs and professionals in contrast to older harvesters who identify more closely with fishing as a "way of life." Similarly, seeing no future in fisheries work, and being encouraged to leave their communities to pursue education and employment, even if only in some form of seasonal migration, our participants tended to imagine their futures outside of fisheries and their communities. Instead they turned their attention toward employment in the oil patch in Alberta or the growing oil industry and other mega-industrial projects in Newfoundland, or in a well-trained profession in a service hub or urban center. At the same time, fisheries jobs did not fit with participants' ideas about what is a good job, because they are dirty and seasonal and it is a tough way to make a living. No doubt, this view reflects the real struggles facing fisheries workers in their communities. It also reflects an intergenerational shift in thinking toward an urban perspective on what makes a good job, perhaps a response to the dominant discourse that young people must get an education and leave their home towns to be viewed as "successful" (see also Norman and Power 2014). At the same time, place-based affections and connections appear to mediate such views on the importance of fishing, because youth from fisheries communities perceive fishing as being more important than do youth who have never lived in such a community. This suggests that any strategies directed at regenerating fisheries and fisheries communities will likely have to build on emotional connections to place and place-based identities.

\section{CONCLUSION}

The "gutting" of the fishing industry and fisheries communities in Newfoundland and Labrador did not just happen. It has been enabled by government and industry policies and strategies that have focused on downsizing the industry and redirecting young people into training and employment in other industries, thus also undermining the intergenerational household- and communitybasis of small-scale fisheries. To that end, it seems unlikely that strategies that focus on individual actors will produce long-term resilience in the industry or in fishing communities. Instead, like Lam and Pitcher (2012:31), we point to the urgent need to invest in "the intergenerational relationships of people to places" if we hope in the future to be able to foster sustainable fisheries and fisheries communities.

Our research with youth in Newfoundland and Labrador suggests that although direct intergenerational connections and supports for entry into fisheries work have been disrupted, our research has also identified strengths on which to build resilient small-scale fisheries and communities in the future (Norman and Power 2014,
Power et al. 2014). Young people's connection to place, and their perception that community vitality is linked to the health of smallscale fisheries, suggest that to foster resiliency, government and industry must invest in strategies that support the entry of young people into fisheries work. Resiliency here does not mean a kind of return to some previous situation, one that was fraught with unsustainable practices and gender inequalities. Instead, resiliency can be understood as those mechanisms that produce healthy and good places to live, in terms of both the biophysical and social worlds. To that end, practices and policies that promote resiliency will need to be innovative, even transformative (Berkes and Ross 2013).

Responses to this article can be read online at: http://www.ecologyandsociety.org/issues/responses. $\mathrm{php} / 6693$

\section{Acknowledgments:}

The Community-University Research for Recovery Alliance (CURRA) initiative is funded by the Social Sciences and Humanities Research Council of Canada (SSHRC) through its Community-University Research Alliance (CURA) program (grant number 833-2007-1027), by the Newfoundland and Labrador Research Development Corporation, Memorial University of Newfoundland, and additional financial and in-kind support from numerous community partners and groups (www. curra.ca).

\section{LITERATURE CITED}

Advanced Education and Skills. 2012. Journeyperson mentorship program helping to meet skilled trades demand. Press Release, 14 November. [online] URL: http://www.releases.gov.nl.ca/releases/2012/ exec/1114n06.htm

Barling, J., C. Loughlin, and E. K. Kelloway. 2002. Development and test of a model linking safety-specific transformational leadership and occupational safety. Journal of Applied Psychology 87:488-496. http://dx.doi.org/10.1037/0021-9010.87.3.488

Berkes, F., and H. Ross. 2013. Community resilience: toward an integrated approach. Society \& Natural Resources 26(1):5-20. http://dx.doi.org/10.1080/08941920.2012.736605

Canadian Policy Research Networks. 2009. Policy actions report: making Newfoundland and Labrador a province of choice for young people. Canadian Policy Research Networks, St. John's, Newfoundland and Labrador, Canada.

Community Accounts. 2006. Multi-variable regional comparison feature. Government of Newfoundland and Labrador, St. John's, Newfoundland and Labrador, Canada. [online] URL: http://nl. communityaccounts.ca/mvrc.asp? =0bfAjIydpaWrnbSTh5FvKRtxKFIVoGNb4q1x6OllJe2m56QjYo \# =0bfAjIydpaWrnbSTh5FvKRtxKFIVoGNb4q1x6O11Je2m56QjYpMp5TMjL69k7GbvrGRd7GTu5vE186n1JuKaZqYqbetdLGSjLmwtK.

qbXd5saSiomayqqSRmpe2u2Swr6q8ycTIjouqoZacmaCft6mwnrO6oque

Faris, J. C. 1979. Cat Harbour: a Newfoundland fishing settlement. Institute of Social and Economic Research, St. John's, Newfoundland and Labrador, Canada. 
Fowler, F. J. 1995. Improving survey questions. Sage, Thousand Oaks, California, USA.

Furlong, A., D. Woodman, and J. Wyn. 2011. Changing times, changing perspectives: reconciling 'transition' and 'cultural' perspectives on youth and young adulthood. Journal of Sociology 47(4):355-370. http://dx.doi.org/10.1177/1440783311420787

Hutchings, J. A., and R. A. Myers. 1995. The biological collapse of Atlantic cod off Newfoundland and Labrador: an exploration of historical changes in exploitation, harvesting technology, and management. Pages 37-93 in R. Arnasson and L. Felt, editors. The North Atlantic fisheries: success, failures and challenges. The Institute of Island Studies, Charlottetown, Prince Edward Island, Canada.

Jackson, L., S. Tirone, C. Donovan, and R. Hood. 2007. Community restructuring and the emotional and social health of youth: a study of a small coastal community in Newfoundland, Canada. Canadian Journal of Community Mental Health 26 (2):71-89.

Khan, A., and B. Neis. 2010. The rebuilding imperative in fisheries: clumsy solutions for a wicked problem? Progress in Oceanography 87:347-356. http://dx.doi.org/10.1016/j.pocean.2010.09.012

Lam, M. E., and T. J. Pitcher. 2012. Fish commoditization: sustainability strategies to protect living fish. Bulletin of Science Technology \& Society 32(1):31-40. http://dx.doi.org/10.1177/027$\underline{0467612444583}$

Lowitt, K. 2011. Examining the foundation for stronger fisheriestourism synergies and increased local seafood consumption in the Bonne Bay region of Newfoundland. Report prepared for Community-University Research for Recovery Alliance (CURRA). CURRA, Memorial University, St. John's, Newfoundland and Labrador, Canada.

MacDonald, M., P. Sinclair, and D. Walsh. 2013. Globalization, fisheries and recovery. Report of the Community-University Research for Recovery Alliance (CURRA) Globalization Group. CURRA, Memorial University, St. John's, Newfoundland and Labrador, Canada.

Memorandum of Understanding (MOU) Steering Committee. 2011. Report of the Independent Chair: MOU Steering Committee. Newfoundland and Labrador Fishing Industry Rationalization and Restructuring. Department of Fisheries and Aquaculture, St. John's, Newfoundland and Labrador, Canada. [online] URL: http://www.gov.nl.ca/fishaq/publications/mou.pdf

Murphy, I., and B. Neis. [date unknown]. Navigating the legislative requirements for fisheries-tourism initiatives in Newfoundland and Labrador. Report prepared for Newfoundland and Labrador Department of Tourism, Culture and Recreation and the Community University Research for Recovery Alliance (CURRA). CURRA, Memorial University, St. John's, Newfoundland and Labrador, Canada. [online] URL: http:// www.curra.ca/documents/TCR Fisheries Tourism RegulationsReport Feb 14 Final to TCR revised.pdf

Neis, B., M. Binkley, S. Gerrard, C. Maneschy, editors. 2005. Changing tides: gender, fisheries and globalization. Fernwood Books, Halifax, Nova Scotia, Canada.
Neis, B., S. Gerrard, and N. G. Power. 2013. Women and children first: the gendered and generational social-ecology of smallerscale fisheries in Newfoundland and Labrador and northern Norway. Ecology and Society 18(4): 64. http://dx.doi.org/10.5751/ ES-06010-180464

Nemec, T. F. 1972. I fish with my brother: the structure and behaviour of agnatic-based fishing crews in a Newfoundland Irish outport. Pages 9-34 in R. Andersen and C. Wadel, editors. North Atlantic fishermen: anthropological essays on modern fishing. Institute of Social and Economic Research, St. John's, Newfoundland and Labrador, Canada.

Norman, M. E., and N. G. Power. 2014. Stuck between 'the rock' and a hard place: rural crisis and re-imagining rural Newfoundland feminine subjectivities. Gender, Place \& Culture: A Journal of Feminist Geography. http://dx.doi.org/10.1080/096$\underline{6369 X .2013 .855707}$

Ommer, R. E. and The Coasts Under Stress Research Project Team. 2007. Coasts under stress: restructuring and socialecological health. McGill-Queens University Press, Kingston, Ontario, Canada.

Palmer, C. T., and P. R. Sinclair. 2000. Expecting to leave: attitudes to migration among high school students on the Great Northern Peninsula of Newfoundland. Newfoundland Studies 16:30-46.

Philpott, M. 2012. Burgeo plant workers get extra three weeks work. The Western Star, 15 August. [online] URL: http://www. thewesternstar.com/News/Local/2012-08-15/article-3052866/Burgeoplant-workers-get-extra-three-weeks-work/1

Porter, M. 1993. Place and persistence in the lives of Newfoundland women. Avebury, Aldershot, UK.

Power, N. G. 2005. What do they call a fisherman? Men, gender, and restructuring in the Newfoundland fishery. Institute of Economic and Social Research, St. John's, Newfoundland and Labrador, Canada.

Power, N. G. 2008. Occupational risks, safety and masculinity: Newfoundland fish harvesters' experiences and understandings of fishery risks. Health, Risk \& Society 10(6):565-583. http://dx. doi.org/10.1080/13698570802167405

Power, N. G., M. E. Norman, and K. Dupré. 2014. Rural youth and emotional geographies: how photovoice and words-alone methods tell different stories of place. Journal of Youth Studies http://dx.doi.org/10.1080/13676261.2014.881983

Rowe, A. 1991. Effect of the crisis in the Newfoundland fishery on women who work in the industry. Women's Policy Office, Government of Newfoundland and Labrador, St. John's, Newfoundland and Labrador, Canada.

Sønvisen, S. A., J. P. Johnsen, and J. Vik. 2011. The Norwegian coastal employment system: what it was and what it is. MAST 10 (1):31-56.

Sumaila, U. R. 2004. Intergenerational cost-benefit analysis and marine ecosystem restoration. Fish and Fisheries 5:329-343. http://dx.doi.org/10.1111/j.1467-2679.2004.00166.x 
Tourangeau, R., L. J. Rips, and K. Rasinski. 2000. The psychology of survey response. Cambridge University Press, Cambridge, UK. http://dx.doi.org/10.1017/CBO9780511819322

Wyn, J., and D. Woodman. 2007. Researching youth in a context of social change: a reply to Roberts. Journal of Youth Studies 10 (3):373-381. http://dx.doi.org/10.1080/13676260701342624 